\title{
SPECTROSCOPIC STUDIES OF MOSQUITO IRIDESCENT VIRUS, ITS CAPSID PROTEINS, LIPIDS, AND DNA
}

\author{
V.M. KRAVCHENKO,${ }^{1}$ YU.P. RUD,${ }^{2}$ L.P. BUCHATSKI, ${ }^{2}$ V.I. MEL'NIK, ${ }^{3}$ \\ K.YU. MOGYLCHAK, ${ }^{1}$ S.P. LADAN,${ }^{1}$ V.M. YASHCHUK ${ }^{1}$ \\ ${ }^{1}$ Faculty of Physics, Taras Shevchenko National University of Kyiv \\ (4, Prosp. Academician Glushkov, Kyiv 01601, Ukraine; e-mail: krav@univ. kiev. ua) \\ ${ }^{2}$ Institute of Biology, Taras Shevchenko National University of Kyiv \\ (2, Prosp. Academician Glushkov, Kyiv 03022, Ukraine)
}

PACS 87.15.mq, 87.80.Dj,

87.14.Cc, 87.14.E-, 87.14.gk

(C) 2012
${ }^{3}$ Department of Photoactivity, Institute of Physics, Nat. Acad. of Sci. of Ukraine (46, Prosp. Nauky, Kyiv 03028, Ukraine)
Mosquito iridescent virus (MIV) is an icosahedric lipid-containing virus which affects mosquitos of Aedes, Culex, Culizeta genera. Apart from mosquitos and other insects, iridoviruses cause the mass death of fish and can cause huge losses for industrial fish breedings. The MIV virion consists of a core of the genetic material (double-stranded viral DNA) surrounded by a capsid (icosahedral protein shell) and further encased in a lipid envelope.

The aim of the work was to determine the role of MIV virion constituents (lipids, capsid proteins, and viral DNA) in the formation of spectral properties of the whole MIV virions.

Measured are UV-Vis absorption, fluorescence, fluorescence excitation, and phosphorescence spectra of MIV virions, their capsid proteins, lipids, and viral DNA dissolved in various buffers.

It is shown that the UV absorption of MIV virions is caused by the absorption of all virion constituents such as capsid proteins, lipids, and viral DNA. The fluorescence of MIV virions at room temperature is mainly due to the fluorescence of capsid proteins. The spectra measured at low temperatures make it possible to identify the type of a nucleic acid (DNA or RNA) inside the virion thanks to the fact that the DNA and RNA phosphorescence spectra are radically different.

\section{Introduction}

Nowadays, viral diseases belong to the most serious threats for the mankind. This is caused by an extremely high rate of infection spread, impossibility to provide prompt and effective vaccination, and severe consequences for the health and economy. Recently, in connection with the rapid development of nanotechnologies, the viruses have become a focus of the rapt attention of physicists, because that kind of biological nanoobjects can be used as a unique template for growing metaldielectric nanoparticles thanks to their prescribed composition, monodispersity, and accessible interior, which allows one to grow dielectric core particles with a narrow size distribution and an accessible core below $80 \mathrm{~nm}$ in diameter [1].

Optical spectroscopy is one of the efficient and informative methods of studying viruses. It provides well reproducible results and is a powerful supplement to conventional biological methods of studying the living organisms. Thus, it allows one to determine the chemical composition of the capsid proteins, the type of a nucleic acid inside the virion (RNA or DNA), and the concentration of virions in the environment or in the tissues of an infected animal. In particular, the fluorescence may be a novel tool to detect viruses and to monitor a viral infection of cells and may be part of a biodefense application [2]. Different peak positions and halfwidths of DNA and RNA fluorescence and phosphorescence bands at low temperatures make it possible to distinguish the DNA viruses from the RNA ones [3-5].

It has been confirmed that the energy structures of DNA, RNA, and complex protein macromolecules are determined mainly by the individual properties of their $\pi$-electron systems, such as aromatic amino acids (tryptophan, tyrosine and phenylalanine), which are centers of intense UV absorption and fluorescence $(\lambda>200$ $\mathrm{nm})$. A success has been reached in modeling the spectra of large and complex native biological macromolecules by the spectra of relatively small $\pi$-electron-containing model compounds [5]. At the same time, it is known that the peak positions of absorption bands and, even in more extent, fluorescence bands and the fluorescence quantum yield are highly dependent on the protein structure and the local environment (neighbouring amino acid residues and solvent molecules) [2].

The present paper is devoted to Mosquito iridescent virus (MIV), an icosahedric lipid-containing virus which affects mosquitos of Aedes, Culex, Culizeta genera. Apart from mosquitos and other insects, iridoviruses 


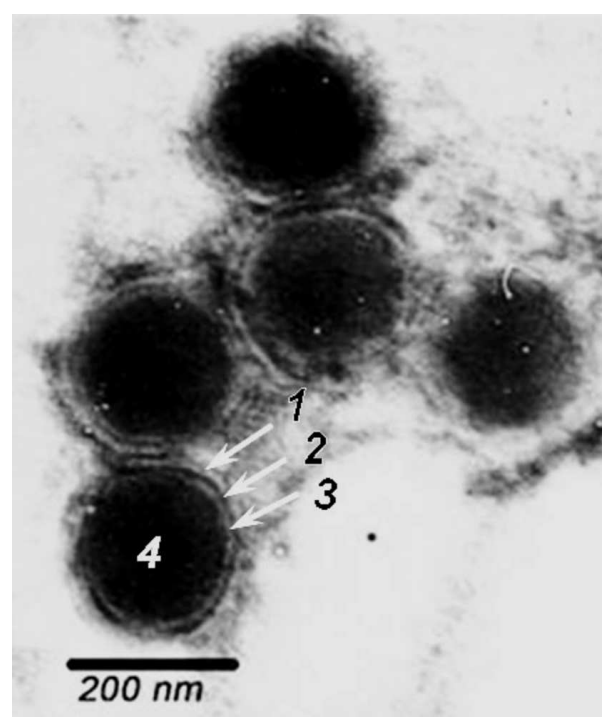

Fig. 1. Micrographs of MIV virions Aedes flavescens: 1 - external lipid shell, 2 - protein capsid, 3 - internal lipid membrane, 4 nucleic acid (DNA)

cause the mass death of fish and can cause huge losses for industrial fish breedings. The MIV is not dangerous for human organisms and is a convenient model object to study. The MIV virion consists of a core of the genetic material (double-stranded viral DNA) surrounded by a capsid (icosahedral protein shell) and further encased in a lipid envelope [6-7]. The diameter of MIV particles is $180 \mathrm{~nm}$ [8].

The aim of the present work was to determine the role of MIV virion constituents (lipids, capsid proteins and viral DNA) in the formation of spectral properties of the whole MIV virions.

\section{Experimental}

MIV virions were extracted from gills, kidneys, and liver of the infected carp at the Institute of Fish Industry of the Ukrainian Academy of Agrarian Sciences [9]. Electron micrographs of MIV virions made with an EM-125 electron microscope are presented in Fig. 1. Measured were the absorption, fluorescence, fluorescence excitation and phosphorescence spectra of MIV virions, their capsid proteins, lipids, and viral DNA dissolved in TRIS$\mathrm{HCl}$, TRIS-HCl-EDTA buffers, dioxane, and distilled water, respectively, as well as the absorption and fluorescence spectra of the three aromatic amino acids dissolved in distilled water. The absorption spectra were recorded at room temperature with a Specord UV-VIS two-beam spectrophotometer. The fluorescence and flu-

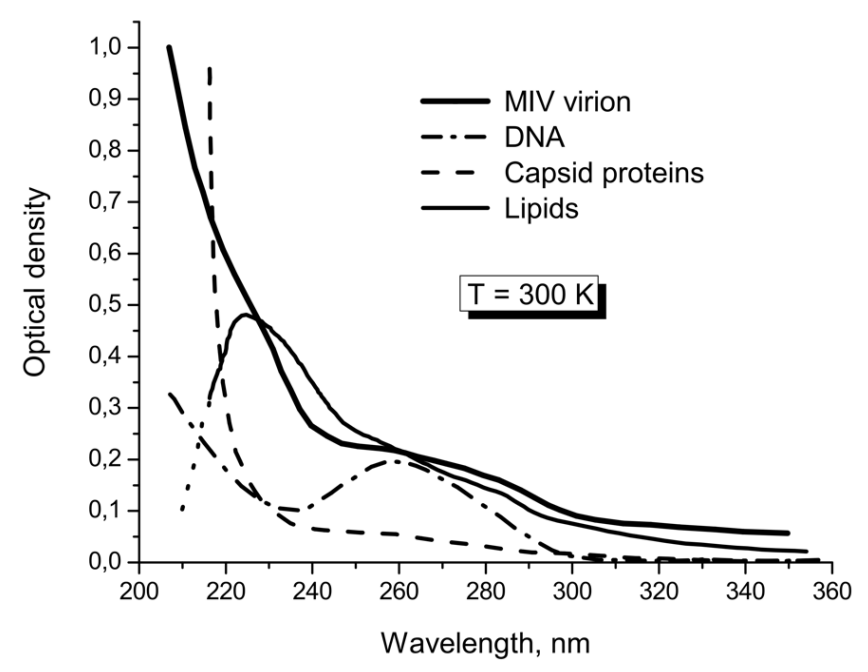

Fig. 2. Absorption spectra of MIV virions, viral DNA, capsid proteins, and lipids. The vertical scale is arbitrary

orescence excitation spectra were recorded at room temperature with a Varian Cary Eclipse fluorescent spectrophotometer, while an MPF-4 Hitachi spectrofluorimeter was used for measuring the fluorescence and phosphorescence spectra at liquid helium temperature. In both cases, a pulsed xenon lamp with continuous emission spectrum was used as the excitation source. The measurements were carried out in the UV and visible regions of spectrum $(\lambda=200-600 \mathrm{~nm})$.

\section{Results and Discussion}

\subsection{Absorption spectra at room temperature}

The absorption spectra of whole MIV virions, their DNA, lipids, and capsid proteins are presented in Fig. 2. It is evident that all virion's constituents (lipids, capsid proteins, and viral DNA) contribute to the MIV virion absorption. Thus, the absorption peak for MIV DNA is located at $260 \mathrm{~nm}$, while the lipids show up a distinct absorption peak at $224 \mathrm{~nm}$ and a shoulder at $\lambda>246$ $\mathrm{nm}$ (Fig. 2). The capsid proteins exhibit an absorption edge, whose position and slope are determined by the concentration of proteins in the buffer. All spectra are corrected for the solvent absorption.

\subsection{Fluorescence and fluorescence excitation spectra at room temperature}

Figure 3 illustrates the fluorescence and fluorescence excitation spectra of MIV virions and the capsid proteins extracted from the virus. It is clear that both types of spectra practically coincide. This fact suggests that the 


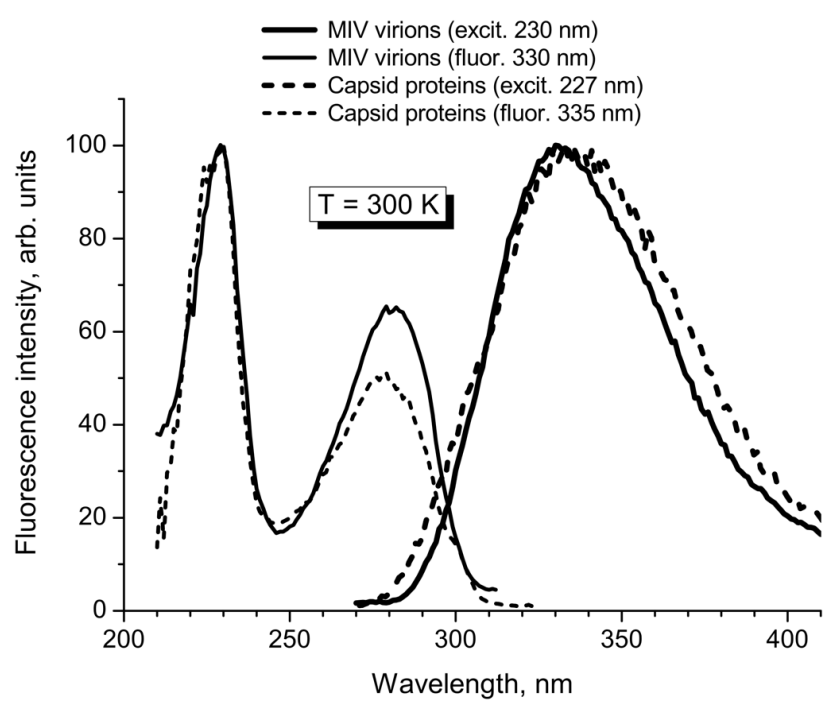

Fig. 3. Normalized fluorescence and fluorescence excitation spectra of MIV virions and MIV capsid proteins

fluorescence centers in MIV virions are the same centers as in the capsid proteins. In other words, the fluorescence of the whole virion at room temperature is caused mainly by the fluorescence of its capsid proteins. All fluorescence spectra of the samples were checked for the background fluorescence of solvents.

Since the centers of intense absorption and fluorescence in the UV spectral region $(\lambda>200 \mathrm{~nm})$ in all protein macromolecules are the aromatic amino acids $[10,11]$, we also measured the fluorescence and the fluorescence excitation spectra of separate aromatic amino acids. Figure 4 illustrates the fluorescence spectra of capsid proteins and three aromatic amino acids. It is seen that the peak positions and halfwidths of the spectral bands do not coincide. In our opinion, this may be caused by the following reasons: i) amino acid fluorescence band position is sensitive to the environment $[2,11]$ and ii) closely located aromatic amino acids may form aggregates within the protein macromolecule. Anyway, further studies are needed to make this issue clear. The same is true with the fluorescence excitation spectra (Fig. 5).

We have ascertained that MIV DNA and lipids do not show any noticeable intrinsic fluorescence at room temperature, which is a well-known fact [11].

\subsection{Fluorescence and phosphorescence spectra at liquid helium temperature}

At liquid helium temperature $(T=5 \mathrm{~K})$, we measured the fluorescence and the phosphorescence of MIV viri-

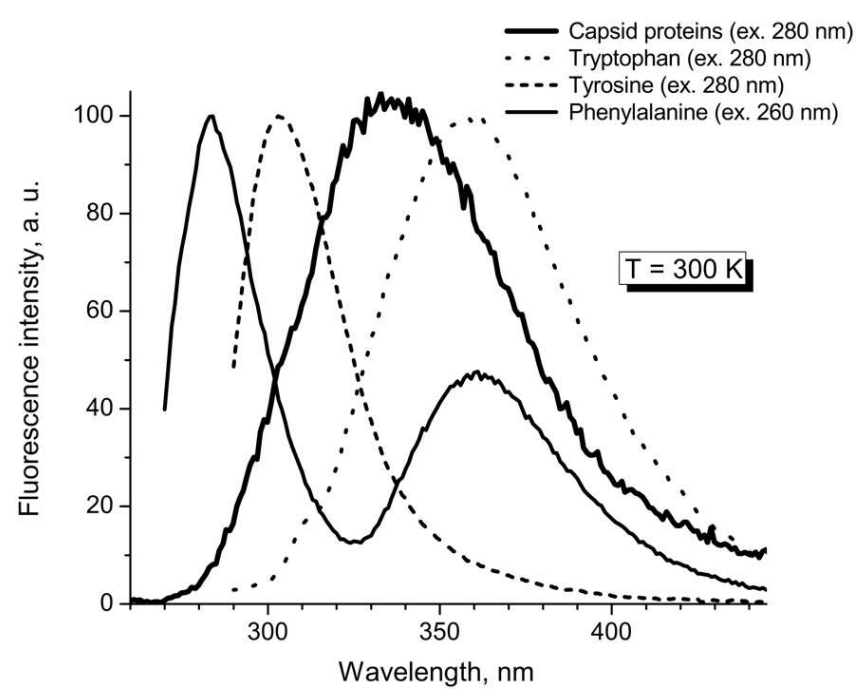

Fig. 4. Normalized fluorescence spectra of MIV capsid proteins and the aromatic amino acids (tryptophan, tyrosine, and phenylalanine)

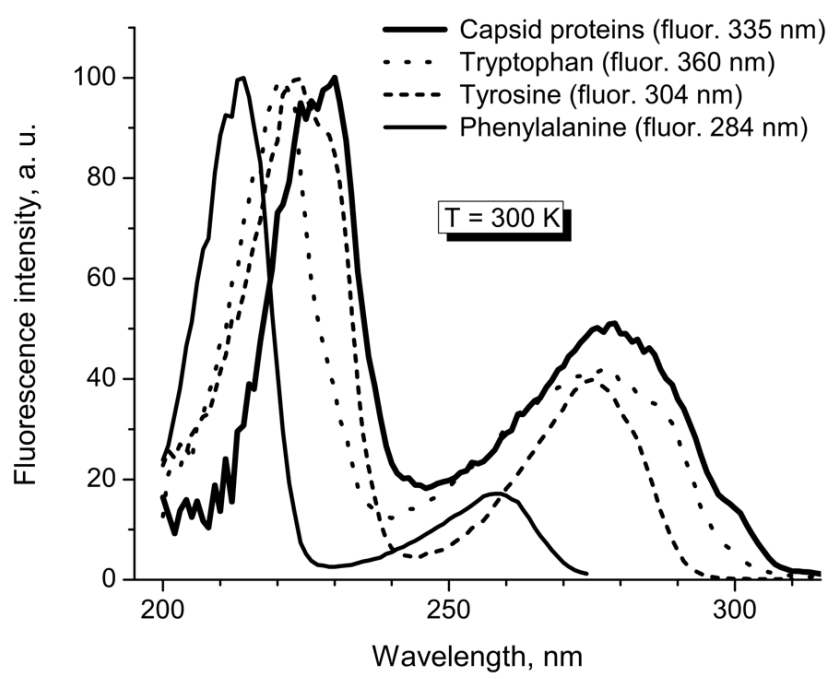

Fig. 5. Normalized fluorescence excitation spectra of MIV capsid proteins and the three aromatic amino acids

ons and MIV DNA. MIV virions exhibit the fluorescence with a peak at $320 \mathrm{~nm}$ and the phosphorescence at 420 $\mathrm{nm}$, while the respective peaks for MIV DNA are located at 350 and $450 \mathrm{~nm}$, respectively (Fig. 6). It is seen that fluorescence bands slightly superimpose on the phosphorescence spectra for both MIV virion and MIV DNA samples. From the figure, it is also clear that the fluorescence spectra of MIV virions and DNA are different. The same is true with the phosphorescence spectra. These facts suggest that the phosphorescence of MIV virions cannot be reduced to the phosphorescence of MIV DNA 


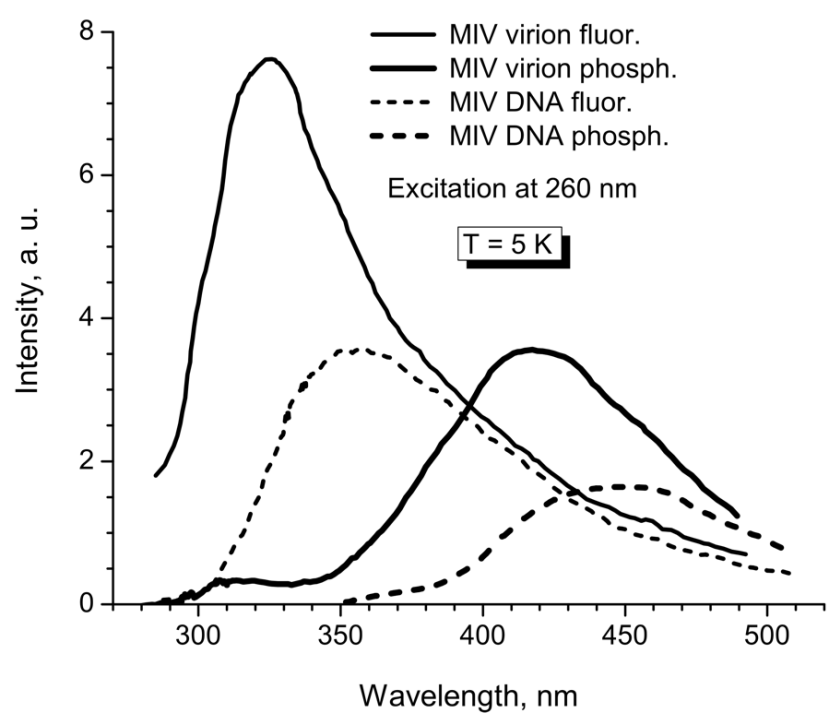

Fig. 6. Fluorescence and phosphorescence spectra of MIV virions and MIV DNA at $T=5 \mathrm{~K}$

only, and the MIV capsid proteins make a certain contribution to the MIV virion phosphorescence spectrum. In addition, the peak position and a smoothed shape of the MIV virion phosphorescence band may be the evidence of the fact that the virion contains DNA rather than RNA (in the latter case, the phosphorescence band would show up some structure).

\section{Conclusions}

It is shown that the UV absorption of MIV virions is caused by the absorption of all virion constituents such as capsid proteins, lipids, and viral DNA. The fluorescence of MIV virions at room temperature is mainly due to the fluorescence of the capsid proteins. The spectra measured at low temperatures make it possible to identify the type of a nucleic acid (DNA or RNA) inside the virion due to the fact that the DNA and RNA phosphorescence spectra are radically different.

The authors would like to acknowledge senior research scientist Prof. S.P. Vesel'skiy from the Department of General Physiology of the Scientific Research Institute of Physiology of Taras Shevchenko National University of Kyiv for masterly extracting lipids from MIV virions, research scientist Dr. M.Yu. Losytsky from the Faculty of Physics of the same university for his invaluable help in measuring the fluorescence and fluorescence excitation spectra of the mentioned samples with a Varian Cary Eclipse fluorescent spectrophotometer, and postgraduate student Ms. S.M. Levchenko from the same faculty for fruitful discussions.
1. C. Radloff, R.A. Vaia, J. Brunton et al., Nano Let. 5, 1187 (2005).

2. A. Alimova, A. Katz, R. Podder et al., Photochem. Photobiol. 80, 41 (2004).

3. V.M. Yashchuk, V.Yu. Kudrya, M.Yu. Losytskyy et al., Mol. Cryst. Liq. Cryst. 467, 311 (2007).

4. V.Yu. Kudrya, V.M. Yashchuk, S.M. Levchenko et al., Mol. Cryst. Liq. Cryst. 497, 93 (2008).

5. V.M. Yashchuk, V.Yu. Kudrya, S.M. Levchenko et al., Mol. Cryst. Liq. Cryst. 535, 93 (2011).

6. X. Yan, N.H. Olson, J.L. Van Etten et al., Nat. Struct. Biol. 7, 101 (2000).

7. X. Yan, Z. Yu, P. Zhang et al., J. Mol. Biol. 385, 1287 (2009).

8. G. Delhon, E.R. Tulman, C.L. Afonso et al., J. Virol. 80, 8439 (2006).

9. Yu.P. Rud and L.P. Buchatski, Veterin. Biotech. No. 14, 5 (2009) (in Ukrainian).

10. P.G. Kostyuk and D.M. Grodzinsky, V.L. Zima et al., Biophysics (Vyshcha Shkola, Kyiv, 1988) (in Russian).

11. J.R. Lakowicz, Principles of Fluorescence Spectroscopy (Springer Sci. + Business Media, New York, 2006).

Received 13.10.11

СПЕКТРОСКОПІЧНІ ДОСЛІДЖЕННЯ ІРИДОВІРУСУ КОМАРА, ЙОГО КАПСИДНИХ БІЛКІВ, ЛІПІДІВ ТА ДНК

В.М. Кравченко, Ю.П. Рудъ, Л.П. Бучацъкий, В.І. Мелъник, К.Ю. Могилъчак, С.П. Ладан, В.М. Ящук

$\mathrm{P}$ е $з$ ю м е

Іридовірус комара Mosquito iridescent virus (MIV) - це ікосаедричний ліпідовмісний вірус, що вражає комарів родів Aedes, Culex, Culizeta. Крім комарів та інших комах іридовіруси можуть спричиняти масову загибель риби і наносити великі збитки промисловому рибництву. Віріон MIV складається з ядра, що містить у собі двонитчату вірусну ДНК, ікосаедричної білкової оболонки (капсиду) та зовнішньої ліпідної оболонки. Метою роботи було визначення внеску складових іридовірусу комара (ліпідів, капсидних білків та вірусної ДНК) у формування спектральних властивостей цілих віріонів. В УФ та видимій областях спектра виміряно спектри поглинання, флюоресценції, фосфоресценції та збудження флюоресценції віріонів MIV, їх капсидних білків, ліпідів та вірусної ДНК у різних буферних розчинах. Показано, що поглинання віріонів в УФ області зумовлене поглинанням усіх їх складових (капсидних білків, ліпідів та вірусної ДНК). Флюоресценція віріонів при кімнатній температурі зумовлена, головним чином, флюоресценцією капсидних білків. Спектри, виміряні при низькій температурі, дають змогу ідентифікувати тип нуклеїнової кислоти всередині віріонів (ДНК чи РНК) завдяки суттєвій відмінності спектрів фосфоресценції ДНК та РНК. 